\title{
PENGARUH PEMANFAATAN TEKNOLOGI INFORMASI DAN SISTIM PENGENDALIAN INTERN TERHADAP KUALITAS LAPORAN KEUANGAN
}

\author{
${ }^{1}$ Herman Darwis, ${ }^{2}$ Meliana \\ Fakultas Ekonomi dan Bisnis Universitas Khairun \\ Email: ${ }^{1}$ herman.darwis@gmail.com, ${ }^{2}$ meliana.mdj@gmail.com
}

Dikirim, 13 Maret 2020

Revisi, 18 Maret 2020

Diterima, 30 Maret 2020

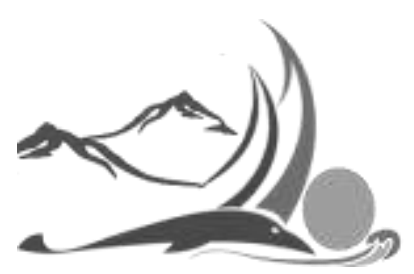

Jurnal Ekonomi, Akuntansi dan Manajemen Multiparadigma

Volume 1, Nomor 2, April 2020

\begin{abstract}
ABSTRAK
Penelitian ini bertujuan untuk memberikan bukti empiris pengaruh pemanfaatan teknologi informasi dan sistem pengendalian intern terhadap kualitas laporan keuangan. Manfaat yang dapat di peroleh bagi pemerintah daerah agar lebih menyadari pentingnya laporan keuangan sebagai alat untuk mengawasi dan menilai kinerja keuangan secara lebih baik. Bagi masyarakat, hasil penelitian ini diharapkan dapat membantu mendeteksi tingkat transpransi dan akuntabilitas pengelolaan keuangan dan mendorong agar lebih berpartisipasi dalam mengawasi serta mendorong peningkatan kinerja keuangan daerah. Hasil Penelitian ini diharapkan dapat bermanfaat sebagai referensi untuk menambah pengetahuan mengenai pengaruh pemanfaatan teknologi informasi dan sistem pengendalian intern terhadap kualitas laporan keuangan. Penelitian ini menggunakan metode penelitian kuantitatif, berupa hubungan sebab akibat (asosiatif). Penelitian asosiatif merupakan salah satu bagian penelitian ex-post facto karena peneliti tidak memanipulasi keadaan variabel yang ada. Penelitian ini rencananya akan memakan waktu selama 6 bulan dan menggunakan teknik pengumpulan data dengan kuesioner yang disebarkan kepada responden. Populasi dari penelitian ini adalah para pegawai yang ada di bagian keuangan pada setiap OPD kota Ternate. Tehnik sampling yang digunakan adalah proporsional random sampling. Tehnik analisa data yang digunakan adalah analisis regresi linier berganda.
\end{abstract}

Kata Kunci: Pemanfaatan Teknologi Informasi, Sistem Pengendalian Intern, Kualitas Laporan keuangan

\begin{abstract}
This study aims to provide empirical evidence of the influence of the use of information technology and internal control systems on the quality of financial statements. The benefits can be obtained for local governments to be more aware of the importance of financial reports as a tool to better monitor and assess financial performance. For the community, the results of this study are expected to help detect the level of transparency and accountability in financial management and encourage more participation in monitoring and encouraging improvements in regional financial performance. The results of this study are expected to be useful as a reference to increase knowledge about the influence of the use of information technology and internal control systems on the quality of financial statements. This research uses quantitative research methods, in the form of causal (associative) relationships. Associative research is one part of ex-post facto research because researchers do not manipulate the state of existing variables. This research is planned to take 6 months and use data collection techniques with a questionnaire distributed to respondents. The population of this study is the employees who are in the financial section in each OPD Ternate city. The sampling technique used is proportional random sampling. The data analysis technique used is multiple linear regression analysis.
\end{abstract}

Keywords: Utilization of Information Technology, Internal Control Systems, Quality of Financial Statement 


\section{PENDAHULUAN}

Seiring perkembangan Akuntansi Sektor Publik di Indonesia, maka kebutuhan akan akuntabilitas sebagai wujud pertanggungjawaban kepada masyarakat atas kinerja pemerintah menjadi suatu tuntutan yang umum. Menguatnya tuntutan tersebut mengharuskan lembaga pemerintah memberikan informasi atas aktivitas dan kinerja kepada publik, sebagai bentuk kewajiban mempertanggungjawabkan keberhasilan atau kegagalan pelaksanaan misi organisasi dalam mencapai tujuan dan sasaran yang telah di tetapkan sebelumnya melalui suatu media pertanggungjawaban yang dilaksanakan secara periodik (Edlin, 2018).

Pertanggungjawaban keuangan Pemerintah Daerah dalam bentuk Laporan Keuangan Pemerintah Daerah (LKPD) yang disusun oleh Kepala Satuan Kerja Pengelolaan Keuangan Daerah (SKPKD) selaku Pejabat Pengelola Keuangan Daerah (PPKD) berdasarkan laporan keuangan Organisasi Perangkat Daerah (OPD) dan laporan pertanggungjawaban pengelolaan perbendaharaan daerah. LKPD yang disajikan pemerintah daerah harus mampu memberikan informasi keuangan yang berkualitas (Siwambudi, 2017)

Kualitas informasi yang terkandung dalam laporan keuangan yang dihasilkan oleh pemerintah daerah harus sesuai dengan kriteria nilai informasi yang disyaratkan oleh peraturan perundang-undangan dan prinsip yang berlaku. Oleh karena itu, pemerintah daerah wajib memperhatikan informasi yang disajikan dalam laporan keuangan untuk keperluan perencanaan, pengendalian, dan pengambilan keputusan. Tentunya laporan keuangan yang disajikan memerlukan pengawasan dan kesesuaian dengan standar yang telah ditetapkan. Sebagai salah satu bentuk pertanggungjawaban dalam penyelenggaraan pemerintahan yang diatur dalam Undang-Undang Nomor 32 Tahun 2014 tentang Pemerintah Daerah, merupakan upaya konkret untuk mewujudkan transparansi dan akuntabilitas pengelolaan keuangan pemerintah, baik pemerintah pusat maupun pemerintah daerah adalah dengan menyampaikan laporan pertanggungjawaban berupa laporan keuangan (Desipradani dan Nuraini 2018).

Untuk menghasilkan Laporan Keuangan Daerah yang berkualitas dibutuhkan dukungan penggunaan teknologi informasi yang dapat membantu mempercepat proses penyampaian dan pemahaman informasi, khususnya dalam mengantisipasi intensitas perubahan-perubahan peraturan pemerintah tentang pengelolaan keuangan pemerintah daerah yang sering terjadi. Meskipun adanya perubahan laporan keuangan yang sebelumnya cash basis menjadi akrual basis. Pemerintah seharusnya menjadikan ini sebagai tantangan agar dapat meningkatkan kualitas laporan keuangan pemerintah daerah itu sendiri (Riandani, 2017).

Sistem pengendalian internal berfungsi memberikan keyakinan tercapainya efektivitas dan efisiensi dalam proses akuntansi terutama dalam menciptakan kualitas laporan keuangan. Oleh karena itu, penerapan sistem pengendalian intern mampu meningkatkan reliabilitas, objektivitas informasi, dan memudahkan proses audit laporan keuangan. Tingginya kualitas laporan keuangan pemerintah daerah juga ditentukan oleh seberapa baik pengendalian internalnya. Jika pengendalian internal lemah, maka akan sulit mendeteksi kecurangan proses akuntansi sehingga dapat menyebabkan bukti audit yang diperoleh dari data akuntansi tersebut menjadi tidak relevan (Herawati, 2014).

Penelitian Soimah (2014), Rahmadani (2015), dan Maysaroh (2018) menemukan bahwa pemanfaatan teknologi informasi berpengaruh terhadap kualitas laporan keuangan pemerintah daerah. Artinya bahwa semakin baik pemanfaatan teknologi informasi, maka semakin baik pula kualitas laporan keuangan pemerintah daerah yang dihasilkan. Sedangkan menurut penelitian Harnoni (2016), Riandani (2017), Puspita dan Amalia (2018) pemanfaatan teknologi informasi tidak berpengaruh terhadap kualitas laporan keuangan 
daerah. Selanjutnya penelitian Harnoni (2016), Kalumata (2016) dan Putri (2017) menemukan bahwa sistem pengendalian intern berpengaruh positif terhadap kualitas laporan keuangan pemerintah daerah. Artinya semakin baik sistim pengendalian internal yang diterapkan maka akan lebih meningkatkan kualitas laporan keuangan pemerintah daerah. Sedangkan menurut penelitian Yensi (2014), Edlin, (2018), Inasari (2018) pengendalian intern tidak pengaruh terhadap kualitas laporan keuangan pemerintah daerah.

Berdasarkan ketidakkonsistenan temuan hasil-hasil penelitian tersebut sehingga penelitian ini mencoba menguji kembali pengaruh pemanfaatan teknologi informasi dan sistem pengendalian internal terhadap kualitas laporan keuangan pemerintah daerah. Penelitian ini sendiri bertujuan untuk memberikan bukti empiris pengaruh pemanfaatan teknologi informasi terhadap kualitas laporan keuangan dan pengaruh sistem pengendalian intern berpengaruh terhadap kualitas laporan keuangan.

Tersedianya teknologi informasi diharapkan dapat membantu dalam proses pelaporan keuangan sehingga dapat menghasilkan informasi laporan keuangan yang berkualitas. Pemerintah Daerah berkewajiban untuk mengembangkan dan memanfaatkan kemajuan teknologi informasi untuk meningkatkan kemampuan mengelola keuangan daerah, dan menyalurkan informasi keuangan daerah (IKD) kepada pelayanan publik. Dengan kemajuan teknologi informasi yang pesat serta potensi pemanfaatannya secara luas, maka dapat membuka peluang bagi berbagai pihak untuk mengakses, mengelola, dan mendayagunakan informasi keuangan daerah secara cepat dan akurat. Untuk itu pemerintah pusat dan pemerintah daerah diwajibkan untuk mengembangkan dan memanfaatkan kemajuan teknologi informasi untuk meningkatkan kemampuan mengelola keuangan daerah dan menyalurkan informasi keuangan daerah kepada pelayanan publik. Pengolahan data dengan memanfaatkan teknologi informasi (komputer dan jaringan) akan memberikan banyak keunggulan baik dari sisi keakuratan/ketepatan hasil operasi maupun predikatnya sebagai mesin multiguna, multiprocessing (Arif, 2017).

Pemanfaatan Teknologi Informasi adalah alat penunjang keberhasilan suatu proses upaya yang dilakukan untuk tercapainya visi dan misi dalam pengelolaan keuangan yang baik. Dengan adanya teknologi informasi ini dapat membantu pegawai-pegawai pemerintahan dalam menyusun laporan keuangan pemerintah serta memudahkan dalam mengolah data keuangan secara sistematis. Pemanfaatan teknologi informasi ini akan meminimalisasi berbagai kesalahan yang diakibatkan human error, karena semua aktivitas pengelolaan keuangan akan tercatat secara lebih sistematis dan pada akhirnya akan mampu menyajikan laporan keuangan daerah yang berkualitas. semakin baik pemanfaatan teknologi maka kualitas laporan akan semakin baik juga (Harnoni, 2016).

Kemajuan teknologi informasi yang pesat serta potensi pemanfaatannya secara luas, maka dapat membuka peluang bagi berbagai pihak untuk mengakses, mengelola, dan mendayagunakan informasi keuangan daerah secara cepat dan akurat. Manfaat lain yang ditawarkan dalam pemanfaatan teknologi informasi adalah kecepatan dalam pemrosesan informasi. Sistem akuntansi di Pemerintah Daerah sudah pasti memiliki transaksi yang kompleks dan besar volumenya. Oleh karena itu, pemanfaatan teknologi informasi akan sangat membantu mempercepat proses pengolahan data transaksi dan penyajian laporan keuangan dan juga pemanfaatan teknologi informasi yang tepat dan didukung oleh keahlian personil yang mengoperasikannya dapat meningkatkan kualitas laporan keuangan (Harnoni, 2016).

Semakin tinggi pemanfaatan teknologi informasi maka kualitas laporan keuangan juga akan semakin tinggi. Pemanfaatan teknologi informasi akan sangat membantu mempercepat proses pengolahan data transaksi dan penyajian laporan keuangan pemerintah daerah (Nurillah, 2014). Pemanfaatan teknologi informasi ini akan 
meminimalisasi berbagai kesalahan, karena semua aktivitas pengelolaan keuangan akan tercatat secara lebih sistematis dan pada akhirnya akan mampu menyajikan laporan keuangan daerah yang berkualitas (Edlin, 2018).

Penelitian Penelitian Soimah (2014), Rahmadani (2015), dan Maysaroh (2018) menemukan bahwa pemanfaatan teknologi informasi berpengaruh terhadap kualitas laporan keuangan pemerintah daerah. Artinya bahwa semakin baik pemanfaatan teknologi informasi, maka semakin baik pula kualitas laporan keuangan pemerintah daerah yang dihasilkan. Berdasarkan uraian di atas maka dapat dirumuskan hipotesis penelitian sebagai berikut :

\section{H1. Pemanfaatan Teknologi Informasi berpengaruh terhadap Kualitas Laporan Keuangan}

Laporan keuangan yang memiliki kualitas nilai informasi yang baik, tidak terlepas dari penerapan sistem pengendalian internal yang baik. Melalui penguatan sistem pengendalian internal, diharapkan upaya perbaikan kualitas laporan keuangan pemerintah daerah lebih dipacu agar kedepannya dapat memperoleh opini wajar tanpa pengecualian. Sebab laporan keuangan yang memperoleh opini wajar tanpa pengecualian berarti laporan tersebut dapat dipercaya sebagai alat pengambil keputusan oleh para pemakai laporan keuangan. Selain itu penerapan sistem pengendalian internal dapat mencegah adanya suatu kegiatan yang tidak sesuai dengan ketentuan yang berlaku. Sehingga dapat memperoleh efisiensi, efektivitas, dan dapat mencegah kerugian Negara (Udiyanti dkk, 2014).

Menurut Warren dkk (2005) dalam Herawati (2014) tujuan sistem pengendalian internal salah satunya adalah untuk mengecek ketelitian dan keandalan data akuntansi. Dengan sistem akuntansi, risiko terjadinya kekeliruan dan kesalahan pencatatan atau perhitungan dapat diminimalisasi sehingga mengurangi kemungkinan pemerintah daerah mengalami kekeliruan. Suatu sistem yang berkualitas, dirancang, dibangun dan dapat bekerja dengan baik apabila bagian-bagian yang terintegrasi dengan sistem tersebut beroperasi sesuai dengan tugas dan tanggung jawabnya masing-masing. Salah satu bagian di dalam sistem informasi akuntansi yang menunjang kelancaran kerja sistem informasi akuntansi tersebut adalah pengendalian internal (internal control).

Sistem pengendalian intern yang dilaksanakan secara optimal dan terus menerus oleh pimpinan dan seluruh pegawai, akan memberikan keyakinan memadai atas tercapainya kegiatan yang efektif dan efisien, keandalan pelaporan keuangan, dan ketaatan terhadap peraturan perundang-undangan yang akan menghasilkan laporan yang berkualitas (Rahmadani, 2015). Saat pemerintah daerah telah menerapkan sistem pengendalian intern pemerintah yang memadai dalam pemerintahan maka pengelolaan keuangan daerah yang transparan dan akuntabel akan meningkat. Hal ini didasarkan pada tujuan penerapan sistem pengendalian intern pemerintah adalah untuk memberikan kenyakinan yang memadai bagi terciptanya pengamanan aset Negara dan keandalan laporan keuangan daerah pemerintah (Zalni, 2013).

Dalam proses penyusunan laporan keuangan daerah, harus didukung oleh Sistem Pengendalian Intern (SPI) yang baik. Peraturan Menteri Dalam Negeri Nomor 13 Tahun 2006 tentang Pedoman Pengelolaan Keuangan Daerah disebutkan bahwa pengendalian intern merupakan proses yang dirancang untuk memberikan keyakinan yang memadai mengenai pencapaian tujuan pemerintah daerah yang tercermin dari keandalan laporan keuangan, efisiensi dan efektivitas pelaksanaan program dan kegiatan, serta dipenuhinya peraturan perundang-undangan. Tingginya kualitas laporan keuangan pemerintah daerah juga ditentukan oleh seberapa baik sistem pengendalian internnya. Jika sistem pengendalian intern lemah, maka akan sulit mendeteksi kecurangan proses akuntansi sehingga dapat 
menyebabkan bukti audit yang diperoleh dari data akuntansi tersebut menjadi tidak relevan (Inasari, 2018)

Sistem pengendalian intern pada pemerintah juga sangat diperlukan guna mendapatkan pengelolaan keuangan daerah yang efektif dan efisien. Sistem pengendalian intern menurut Peraturan Pemerintah No. 60 Tahun 2008 yang mengatur tentang Sistem Pengendalian Intern Pemerintah (SPIP) adalah 3 proses yang integral pada kegiatan dan tindakan yang dilakukan secara terus menerus oleh pimpinan dan tercapainya tujuan organisasi melalui kegiatan yang efektif dan efisien, keandalan pelaporan keuangan, pengamanan aset negara, dan ketaatan terhadap peraturan perundang-undangan. Sistem pengendalian internal yang baik dalam suatu pemerintahan akan mampu menciptakan keseluruhan proses kegiatan yang baik pula, sehingga akan memberikan keyakinan yang memadai bagi terciptanya pengamanan asset Negara dan keandalan laporan keuangan daerah pemerintah, dalam hal tersebut akan memberikan dampak positif bagi pengelolaan keuangan daerah (Zalni, 2013)

Penelitian Harnoni (2016), Kalumata (2016) dan Putri (2017) menemukan bahwa sistem pengendalian intern berpengaruh positif terhadap kualitas laporan keuangan pemerintah daerah. Artinya semakin baik sistem pengendalian internal yang diterapkan maka akan lebih meningkatkan kualitas laporan keuangan pemerintah daerah. Berdasarkan uraian di atas maka dapat dirumuskan hipotesis penelitian sebagai berikut :

\section{H2. Sistem Pengendalian Intern berpengaruh terhadap Kualitas Laporan Keuangan.}

\section{METODE PENELITIAN}

Penelitian ini menggunakan metode penelitian kuantitatif, berupa hubungan sebab akibat (asosiatif). Penelitian ini memakan waktu selama 6 bulan dan bertempat pada Organisasi Perangkat Daerah (OPD) Kota Ternate khususnya di bagian Keuangan. Penelitian ini sendiri menggunakan metode survei dengan kuesioner. Populasi dalam penelitian ini adalah seluruh pegawai pengelola keuangan dari 30 Organisasi Perangkat Daerah (OPD)Kota Ternate yang terdiri dari 23 Dinas, 6 Badan dan 1 Kantor. sehingga jumlah populasi sebanyak 143 orang. Teknik sampling yang digunakan adalah proporsional random sampling, karena populasi tersebar secara acak di setiap Dinas. Ukuran sampel menggunakan rumus Yamane (Khan, 2005) dengan total jumlah sampel sebanyak 105 responden.

Kualitas informasi laporan keuangan yang digunakan penelitian ini diukur dengan menggunakan 40 dimensi karakteristik kualitatif laporan keuangan pada Kerangka Konseptual PSAP yaitu relevan, andal, dapat diperbandingkan, dan dapat dipahami. Pemanfaatan teknologi informasi diukur dengan menggunakan dimensi yang dikembangkan oleh Willian dan Sawyer dalam Siahaan (2017) yaitu dimensi kemudahan penggunaan teknologi informasi dan kegunaan. Pengendalian intern dalam penelitian ini diukur dengan menggunakan kuesioner dari Soimah (2014). Teknik analisa data yang digunakan adalah analisis regresi linier berganda didasarkan atas hubungan fungsional maupun kausal antara satu variabel independen dengan beberapa variabel dependen (Sugiyono, 2012).

\section{HASIL PENELITIAN DAN PEMBAHASAN}

Penyajian statistik deskriptif bertujuan untuk menggambarkan karakter sampel dalam penelitian maupun memberikan deskripsi variabel yang disajikan lewat nilai minimum, nilai maksimum, nilai rata-rata serta standar deviasi dari setiap variabel yang digunakan dalam penelitian ini. 
Tabel 1 Statistik Deskriptif

\begin{tabular}{cccccc}
\hline Variabel & N & Minimum & Maximum & Mean & Std. Deviation \\
\hline PTI & 85 & 34 & 60 & 47.27 & 5.907 \\
\hline SPI & 85 & 27 & 45 & 35.94 & 3.567 \\
\hline KLK & 85 & 27 & 45 & 37.71 & 3.988 \\
\hline Valid N (listwise) & 85 & & & & \\
\hline Sumber Data diolah & & & & &
\end{tabular}

Statistik deskriptif menyajikan informasi tentang karakteristik variabel penelitian, antara lain minimum, maksimum, mean, dan standar deviasi. Pengukuran rata-rata (mean) merupakan cara yang paling umum digunakan untuk mengukur nilai sentral dari suatu distribusi data. Sedangkan standar deviasi merupakan perbedaan nilai data yang diteliti dengan nilai rata-ratanya. Berdasarkan tabel di atas dapat dilihat untuk variabel pemanfaatan teknologi informasi nilai minimum adalah 60, nilai maksimum 60, mean sebesar 47,27 dan standar deviasi sebesar 5,907. Variabel sistem pengendalian internal nilai minimum adalah 27, nilai maksimum 45, mean sebesar 35,94 dan standar deviasi sebesar 3,567. Variabel kualitas laporan keuangan nilai minimum adalah 27, nilai maksimum 45, mean sebesar 37,71 dan standar deviasi sebesar 3,988.

Tabel 2 Uji Validitas Variabel Pemanfaatan Teknologi Informasi

\begin{tabular}{|c|c|c|c|c|c|c|c|c|c|c|c|c|}
\hline & $\mathrm{x} 1.1$ & $x 1.2$ & $x 1.3$ & x1.4 & x1.5 & $x 1.6$ & $\mathbf{x} 1.7$ & $\times 1.8$ & $\mathbf{x 1 . 9}$ & x1.10 & x1.11 & $\mathbf{x 1 . 1 2}$ \\
\hline $\begin{array}{l}\text { Pearson } \\
\text { Correlation }\end{array}$ & $.659^{* *}$ & $.638^{* *}$ & $.710^{* *}$ & $.776^{* *}$ & $.806^{* *}$ & $.769^{* *}$ & $.815^{* *}$ & $.774^{* \star}$ & $.821^{*}$ & $.802^{* *}$ & $.784^{* *}$ & $.808^{* \star}$ \\
\hline Sig. (2-tailed) & .000 & .000 & .000 & .000 & .000 & .000 & .000 & .000 & .000 & .000 & .000 & .000 \\
\hline $\mathrm{N}$ & 85 & 85 & 85 & 85 & 85 & 85 & 85 & 85 & 85 & 85 & 85 & 85 \\
\hline
\end{tabular}

Sumber Data diolah

Tabel 3 Uji Validitas Variabel Sistim Pengendalian Internal

\begin{tabular}{lrrrrrrrrr}
\hline & $\mathbf{x 2 . 1}$ & $\mathbf{x 2 . 2}$ & $\mathbf{x 2 . 3}$ & $\mathbf{x 2 . 4}$ & $\mathbf{x 2 . 5}$ & $\mathbf{x 2 . 6}$ & $\mathbf{x 2 . 7}$ & $\mathbf{x 2 . 8}$ & $\mathbf{x 2 . 9}$ \\
\hline Pearson Correlation & $.759^{* *}$ & $.612^{* *}$ & $.651^{* *}$ & $.715^{* *}$ & $.675^{* *}$ & $.725^{* *}$ & $.615^{* *}$ & $.559^{* *}$ & $.667^{* *}$ \\
\cline { 2 - 9 } & .000 & .000 & .000 & .000 & .000 & .000 & .000 & .000 & .000 \\
\hline $\mathrm{S}$ & 85 & 85 & 85 & 85 & 85 & 84 & 85 & 85 & 85 \\
\hline
\end{tabular}

Sumber Data diolah

Tabel 4 Uji Validitas Variabel Kualitas Laporan Keuangan

\begin{tabular}{|c|c|c|c|c|c|c|c|c|c|}
\hline & y.1 & y.2 & y.3 & y.4 & y.5 & y.6 & y.7 & y.8 & y.9 \\
\hline Pearson Correlation & $.732^{* *}$ & $.627^{* *}$ & $.804^{* *}$ & $.767^{* *}$ & $.716^{* *}$ & $.807^{* *}$ & $821^{* *}$ & $.746^{* *}$ & $.776^{* *}$ \\
\hline Sig. (2-tailed) & .000 & .000 & .000 & .000 & .000 & .000 & .000 & .000 & .000 \\
\hline $\mathrm{N}$ & 85 & 85 & 85 & 85 & 85 & 85 & 85 & 85 & 85 \\
\hline
\end{tabular}

Sumber Data diolah

Berdasarkan tabel-tabel tersebut di atas terlihat nilai signifikansi dari setiap butir pertanyaan lebih kecil dari 0,05 sehingga dapat dikatakan bahwa semua butir-butir pertanyaannya adalah valid. Berdasarkan tabel 5 menunjukkan nilai Cronbach Alpha berada di atas angka 0,06 untuk masing-masing variabel dalam penelitian ini. Hal ini berarti bahwa instrumen yang digunakan untuk mengukur variabel dalam penelitian ini dianggap reliabel dan dapat dapat digunakan untuk mengukur setiap variabel dalam penelitian ini. 
Tabel 5 Uji Reliabilitas

\begin{tabular}{lccc}
\hline \multicolumn{1}{c}{ Variabel } & Cronbach's Alpha & N of Items & Keterangan \\
\hline Pemanfaatan Teknologi Informasi & 0.932 & 12 & Reliabel \\
\hline Sistem Pengendalian Internal & 0.844 & 9 & Reliabel \\
\hline Kualitas Laporan Keuangan & 0.903 & 9 & Reliabel \\
\hline
\end{tabular}

Sumber: data diolah

Berdasarkan tabel 6 hasil uji normalitas di atas, dapat terlihat bahwa nilai Kolmogorov-Smirnov untuk persamaan regresi signifikan di atas 0.05. Hal ini berarti model regresi memenuhi asumsi normalitas. Dari hasil uji normalitas dengan uji statistik dapat disimpulkan bahwa model-model regresi dalam penelitian ini layak digunakan karena memenuhi asumsi normalitas.

Tabel 6 One-Sample Kolmogorov-Smirnov Test

\begin{tabular}{llr}
\hline & & \multicolumn{1}{c}{$\begin{array}{c}\text { Unstandardized } \\
\text { Residual }\end{array}$} \\
\hline $\mathrm{N}$ & & 85 \\
\cline { 2 - 3 } & Mean & .0000000 \\
\cline { 2 - 3 } & Std. Deviation & .97195532 \\
\cline { 2 - 3 } & Absolute & .128 \\
\cline { 2 - 3 } & Positive & .086 \\
\cline { 2 - 3 } & Negative & .128 \\
\hline Test Statistic & & .128 \\
\hline Asymp. Sig. (2-tailed) & & $.071^{\mathrm{c}}$ \\
\hline a. Test distribution is Normal. & \\
\hline b. Calculated from data. & \\
\hline c. Lilliefors Significance Correction. & \\
\hline \multicolumn{2}{c}{ Sumber: data diolah } \\
\end{tabular}

Tabel 7 Hasil Uji Multikolinieritas

\begin{tabular}{lcc}
\hline \multirow{2}{*}{ Model } & \multicolumn{2}{c}{ Collinearity Statistics } \\
\cline { 2 - 3 } & Tolerance & VIF \\
\hline (Constant) & & \\
\hline PTI & .687 & 1.455 \\
\hline SPI & .687 & 1.455 \\
\hline Sumber: data diolah & &
\end{tabular}

Berdasarkan hasil uji multikolinieritas yang disajikan dalam tabel 7 dapat disimpulkan bahwa data dalam penelitian ini tidak mengalami masalah multikolinieritas. Hal ini dapat dilihat dari nilai tolerance yang lebih besar dari kriteria yang digunakan dan nilai VIF yang lebih kecil dari kriterianya untuk seluruh variabel. Hasil menunjukkan bahwa tidak adanya korelasi yang kuat antara variabel independen. 


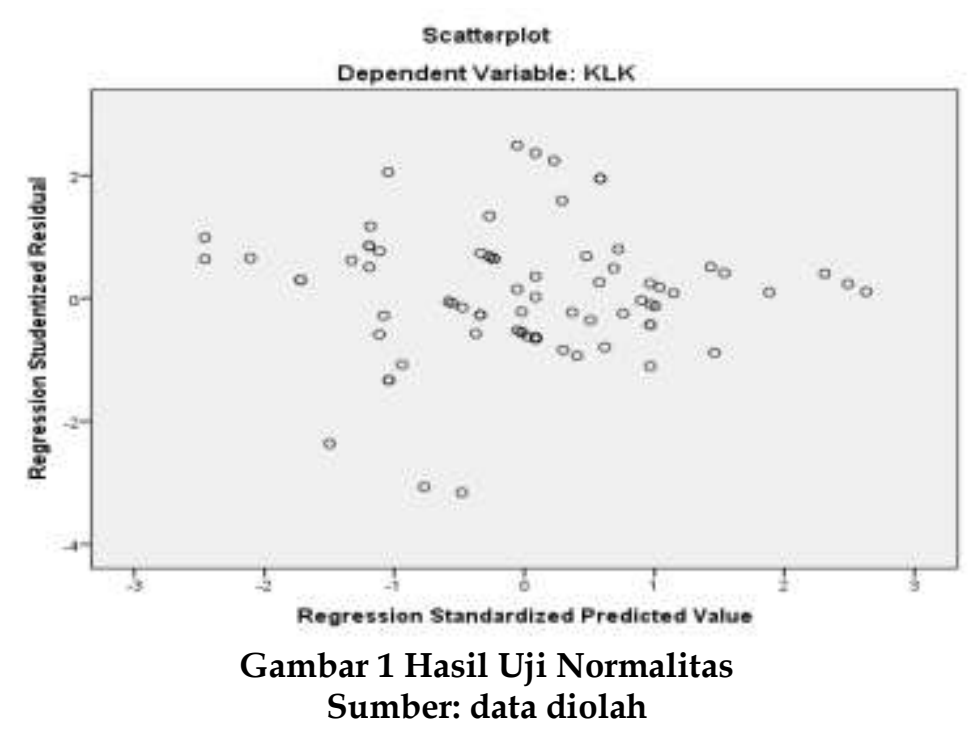

Berdasarkan gambar di atas terlihat bahwa data tersebar secara acak dan tidak terjadi masalah Heteroskedasitas. Model regresi yang baik adalah yang homokedastisitas atau yang tidak terjadi heteroskedastisitas.

Tabel 8 Rekapitulasi Regresi Berganda

\begin{tabular}{|c|c|c|c|}
\hline Variabel Dependen & Variabel Independen & Koefisien & Signifikansi \\
\hline \multirow{2}{*}{$\begin{array}{l}\text { Kualitas Laporan } \\
\text { Keuangan }\end{array}$} & Pemanfaatan Teknologi Informasi & 0,283 & 0,000 \\
\hline & Sistem Pengendalian Internal & 0,374 & 0,001 \\
\hline Constanta & $=10.888$ & & \\
\hline $\mathrm{R}$ & $=0,667$ & & \\
\hline R Square & $=0,445$ & & \\
\hline Adjusted R Square & $=0,431$ & & \\
\hline F hitung & $=32,809$ & & \\
\hline Sig. & $=0,000$ & & \\
\hline $\mathrm{N}$ & $=85$ & & \\
\hline
\end{tabular}

Sumber: data diolah

Dari persamaan tersebut dapat diinterpretasi bahwa koefisien konstanta sebesar 10,888 menunjukkan bahwa apabila variabel independen sebesar nol, maka nilai kualitas laporan keuangan sebesar 10,888. Koefisien regresi variabel pemanfaatan teknologi informasi sebesar 0,283 menunjukkan bahwa apabila variabel pemanfaatan teknologi informasi meningkat sebesar satu satuan maka variabel kualitas laporan keuangan akan meningkat sebesar 0,283, dengan asumsi variabel lainnya konstan. Nilai signifikansi variabel pemanfaatan teknologi informasi sebesar 0,000 lebih kecil dari taraf signifikan yang ditentukan sebesar 0,05. Hal ini berarti hipotesis yang menyatakan bahwa "Pemanfaatan Teknologi Informasi berpengaruh terhadap kualitas laporan keuangan" dapat diterima atau Ha diterima. Koefisien regresi variabel sistem pengendalian internal sebesar 0,374 menunjukkan bahwa apabila variabel sistem pengendalian internal meningkat sebesar satu satuan maka kualitas laporan keuangan akan meningkat sebesar 0,374, dengan asumsi variabel lainnya konstan. Nilai signifikansi variabel sistem pengendalian internal sebesar 0,001 lebih kecil dari taraf signifikan yang ditentukan sebesar 0,05. Hal ini berarti hipotesis yang menyatakan bahwa "sistem pengendalian internal berpengaruh terhadap kualitas laporan keuangan tidak dapat ditolak atau Ha diterima. Koefisien korelasi (R) sebesar 0,243 
menunjukkan korelasi (hubungan) antara variabel independen dengan variabel dependen memiliki hubungan yang lemah. Koefisien determinasi (Adjusted R square) sebesar 0,431 menunjukkan bahwa variasi naik turunnya variabel kualitas laporan keuangan dipengaruhi oleh variasi naik turunnya variabel independen sebesar $43,1 \%$ sedangkan sisanya sebesar $56,9 \%$ dipengaruhi oleh variabel lain yang tidak diamati. Nilai F hitung sebesar 32,809 dan signifikansi sebesar 0,00 nilai ini lebih kecil dari taraf signifikan 0,05, sehingga secara simultan atau serempak variabel independen berpengaruh terhadap variabel dependen.

Hasil penelitian ini menemukan bahwa pemanfaatan teknologi informasi berpengaruh terhadap kualitas laporan keuangan, artinya bahwa semakin dimanfaatkan teknologi informasi maka kualitas laporan keuangan akan sangat baik, demikian pula sebaliknya apabila kurang memanfaatkan teknologi informasi akan mengakibatkan kualitas laporan keuangan akan kurang baik. Hal ini terjadi karena teknologi informasi dimungkinkan dapat membantu pegawai-pegawai pemerintahan dalam menyusun laporan keuangan pemerintah serta memudahkan dalam mengolah data keuangan secara sistematis, sehingga Pemanfaatan teknologi informasi akan meminimalisasi berbagai kesalahan yang diakibatkan human error, karena semua aktivitas pengelolaan keuangan akan tercatat secara lebih sistematis dan pada akhirnya akan mampu menyajikan laporan keuangan daerah yang berkualitas.

Sistem akuntansi di Pemerintah Daerah memiliki transaksi yang kompleks dan besar volumenya. Oleh karena itu, pemanfaatan teknologi informasi akan sangat membantu mempercepat proses pengolahan data transaksi dan penyajian laporan keuangan dan juga pemanfaatan teknologi informasi yang tepat dan didukung oleh keahlian personil yang mengoperasikannya dapat meningkatkan kualitas laporan keuangan (Harnoni, 2016). Semakin tinggi pemanfaatan teknologi informasi maka kualitas laporan keuangan juga akan semakin tinggi. Pemanfaatan teknologi informasi akan sangat membantu mempercepat proses pengolahan data transaksi dan penyajian laporan keuangan pemerintah daerah (Nurillah, 2014). Pemanfaatan teknologi informasi ini akan meminimalisasi berbagai kesalahan, karena semua aktivitas pengelolaan keuangan akan tercatat secara lebih sistematis dan pada akhirnya akan mampu menyajikan laporan keuangan daerah yang berkualitas (Edlin, 2018).

Hasil penelitian ini konsisten dengan penelitian yang dilakukan oleh Soimah (2014), Rahmadani (2015), dan Maysaroh (2018) menemukan bahwa pemanfaatan teknologi informasi berpengaruh terhadap kualitas laporan keuangan pemerintah daerah. Sedangkan penelitian ini bertentangan dengan penelitian yang dilakukan oleh Harnoni (2016), Riandani (2017), Puspita dan Amalia (2018) yang menemukan bahwa pemanfaatan teknologi informasi tidak berpengaruh terhadap kualitas laporan keuangan daerah.

Hasil penelitian ini menemukan bahwa sistem pengendalian internal berpengaruh terhadap kualitas laporan keuangan, artinya bahwa semakin baik sistem pengendalian internal, maka akan semakin berkualitas laporan keuangan, demikian pula sebaliknya apabila sistem pengendalian internalnya tidak baik maka kualitas laporan keuangan juga akan tidak baik. Hal ini terjadi karena sistem pengendalian internal dapat mencegah adanya suatu kegiatan yang tidak sesuai dengan ketentuan yang berlaku. Menurut Warren dkk (2005) dalam Herawati (2014) tujuan sistem pengendalian internal salah satunya adalah untuk mengecek ketelitian dan keandalan data akuntansi. Dengan sistem akuntansi, risiko terjadinya kekeliruan dan kesalahan pencatatan atau perhitungan dapat diminimalisasi sehingga mengurangi kemungkinan pemerintah daerah mengalami kekeliruan.

Sistem pengendalian intern yang dilaksanakan secara optimal dan terus menerus oleh pimpinan dan seluruh pegawai, akan memberikan keyakinan memadai atas tercapainya kegiatan yang efektif dan efisien, keandalan pelaporan keuangan, dan ketaatan terhadap 
peraturan perundang-undangan yang akan menghasilkan laporan yang berkualitas (Rahmadani, 2015). Saat pemerintah daerah telah menerapkan sistem pengendalian intern pemerintah yang memadai dalam pemerintahan maka pengelolaan keuangan daerah yang transparan dan akuntabel akan meningkat. Hal ini didasarkan pada tujuan penerapan sistem pengendalian intern pemerintah adalah untuk memberikan keyakinan yang memadai bagi terciptanya pengamanan asset Negara dan keandalan laporan keuangan daerah pemerintah (Zalni, 2013).

Hasil penelitian ini konsisten dengan penelitian yang dilakukan oleh Harnoni (2016), Kalumata (2016) dan Putri (2017) menemukan bahwa sistem pengendalian intern berpengaruh positif terhadap kualitas laporan keuangan pemerintah daerah. Sedangkan hasil penelitian ini bertentangan dengan penelitian yang dilakukan oleh Yensi (2014), Edlin, (2018), Inasari (2018) pengendalian intern tidak pengaruh terhadap kualitas laporan keuangan pemerintah daerah.

\section{SIMPULAN}

Berdasarkan pembahasan di atas maka kesimpulan dan saran dari penelitian ini adalah sebagai berikut:

1. Hasil penelitian ini menemukan bahwa pemanfaatan teknologi informasi berpengaruh terhadap kualitas laporan keuangan, artinya bahwa semakin dimanfaatkan teknologi informasi maka kualitas laporan keuangan akan sangat baik, demikian pula sebaliknya apabila kurang memanfaatkan teknologi informasi akan mengakibatkan kualitas laporan keuangan akan kurang baik.

2. Hasil penelitian ini menemukan bahwa sistem pengendalian internal berpengaruh terhadap kualitas laporan keuangan, artinya bahwa semakin baik sistem pengendalian internal, maka akan semakin berkualitas laporan keuangan, demikian pula sebaliknya apabila sistem pengendalian internalnya tidak baik maka kualitas laporan keuangan juga akan tidak baik.

3. Diharapkan kepada pemerintah daerah khususnya pemda Kota Ternate agar memperhatikan penerapan pemanfaatan teknologi informasi dan sistem pengendalian internal karena terbukti dapat mempengaruhi kualitas laporan keuangan.

4. Bagi peneliti selanjutnya dapat menambahkan variabel lain yang dimungkinkan dapat mempengaruhi kualitas laporan keuangan dan juga dapat menambah sampel penelitian pada pemerintah daerah lainnya.

\section{DAFTAR PUSTAKA}

Arif, Rahman. 2017. Pengaruh Pemanfaatan Teknologi Informasi, Komitmen Organisasi dan Kejelasan Tujuan Terhadap Kualitas Informasi Laporan Keuangan Pemerintah Daerah (Studi Empiris Pada SKPD Kota Padang Panjang).

Desipradani dan Fitri Nuraini. 2018 Variabel Berpengaruh Terhadap Kualitas Laporan Keuangan Pemerintah Kota Surabaya. Majalah Ekonomi _ ISSN No. 1411-9501_Vol. XXIII No. 2_Desember 2018.

Edlin. Debby Nadya. 2018. Pengaruh Kapasitas Sumber Daya Manusia, Pemanfaatan Teknologi Informasi Dan Sistem Pengendalian Intern Pemerintah Terhadap Kualitas Laporan Keuangan Pemerintah Daerah Dengan Komitmen Organisasi Sebagai Variabel Moderating. JOM FEB, Volume 1 Edisi 1 (Januari - Juni 2018).

Harnoni. 2016. Pengaruh Kapasitas Sumber Daya Manusia, Pemanfaatan Teknologi Informasi, dan Sistem Pengendalian Internal Terhadap Kualitas Laporan Keuangan Pemerintah Daerah (Studi Pada SKPD Di Kabupaten Kepulauan Anambas). Jom FEKON Vol. 3 No. 1 (Februari) 2016 
Herawati, Tuti. 2014. Pengaruh sistem pengendalian intern terhadap kualitas laporan keuangan (Survei pada organisasi perangkat daerah pemda Cianjur). Study $\mathcal{E}$ Accounting Research, Vol XI, No. 1, ISSN: 1693-4482.

Inasari, Reni Realita. 2018. Analisis Faktor-Faktor Yang Mempengaruhi Kualitas Laporan Keuangan (Studi Empiris pada Satuan Kerja Perangkat Daerah Kabupaten Sukoharjo).

Kalumata, Merlyn C. T., Ventje Ilat, Jessy D. L. Warongan. 2016. Pengaruh Kompetensi Sumber Daya Manusia, Teknologi Informasi, Reviu Laporan Keuangan dan Sistem Pengendalian Internal Terhadap Kualitas Laporan Keuangan Pada Pemerintah Provinsi Sulawesi Utara.

Maysaroh, Katin Wilda. Pengaruh Kompetensi Sumber Daya Manusia, Penerapan Sistem Pengendalian Intern, Penerapan Standar Akuntansi Pemerintahan dan Pemanfaatan Teknologi Informasi Terhadap Kualitas Laporan KeuanganPemerintah Daerah (Persepsi Aparatur Pemerintah Daerah Pada SKPD Kabupaten Sukoharjo).

Nurillah, As Syifa dan Dul Muid. 2014. Pengaruh Kompetensi Sumber Daya Manusia, Penerapan Sistem Akuntansi Keuangan Daerah (SAKD), Pemanfaatan Teknologi Informasi, dan Sistem Pengendalian Intern Terhadap Kualitas Laporan Keuangan Pemerintah Daerah (Studi Empiris Pada SKPD Kota Depok). Diponegoro Journal Of Accounting. Volume 3 Nomor .2 Tahun 2014, ISSN (Online): 2337-3806

Puspita, Deasy Hary Rahman, Dewi Amalia. 2018. Pengaruh Kapasitas Sumber Daya Manusia dan Pemanfaatan Teknologi Informasi Terhadap Kualitas Laporan Keuangan Pemerintah Daerah dengan Variabel Intervening Sistem Pengendalian Intern Pemerintah Studi Pada Satuan Kerja Perangkat Daerah Kota Cirebon.

Putri, Pretisila Kartika. 2017. Analisis Faktor Yang Mempengaruhi Kualitas Informasi Laporan Keuangan Pemerintah Daerah dengan Pemoderasi Pengawasan Keuangan Daerah. Soedirman Accounting Review. Volume 02 Nomor 02 Tahun 2017, 155-173.

Rahmadani, Suci. 2015. Pengaruh Kompetensi Sumber Daya Manusia, Sistem Akuntansi Keuangan Daerah, Pemanfaatan Teknologi Informasi dan Sistem Pengendalian Intern Terhadap Kualitas Laporan Keuangan Pemerintah Daerah (Studi Pada Satuan Kerja Perangkat Daerah Kabupaten Pasaman Barat). JOM FEKON Vol. 2 No. 2 Oktober 2015.

Riandani, Riedy. 2017. Pengaruh Kompetensi Sdm, Pemanfaatan Teknologi Informasi, dan Pengendalian Intern Terhadap Kualitas Laporan Keuangan (Studi Empiris Pada SKPD Kab. Limapuluh Kota).

Siwambudi I Gusti Ngurah, Gerianta Wirawan Yasa, I Dewa Nyoman Badera. 2017. Komitmen Organisasi Sebagai Pemoderasi Pengaruh Kompetensi SDM dan Sistem Pengendalian Intern Pada Kualitas Laporan Keuangan. E-Jurnal Ekonomi dan Bisnis Universitas Udayana, ISSN: 2337-3067.

Soimah, Siti. 2014. Pengaruh Kapasitas Sumber Daya Manusia, Pemanfaatan Teknologi Informasi dan Sistem Pengendalian Intern Pemerintah Terhadap Kualitas Laporan Keuangan Pemerintah Daerah Kabupaten Bengkulu Utara, Skripsi. Fakultas Ekonomi dan Bisnis

Sugiyono. (2012). Statistika Untuk Penelitian. Bandung: Alfabeta.

Udiyanti Ni Luh Nyoman Ari, Anantawikrama Tungga Atmadja, Nyoman Ari Surya Darmawan. 2014. Pengaruh Penerapan Standar Akuntansi Pemerintahan, Sistem Pengendalian Internal, dan Kompetensi Staf Akuntansi Terhadap Kualitas Laporan Keuangan Pemerintah Daerah (Studi Kasus Pada SKPD Kabupaten Buleleng).

Yensi, Desy Sefri, Amir Hasan dan Yuneita Anisma. 2014. Pengaruh Kompetensi Sumber Daya Manusia, Penerapan Sistem Akuntansi Keuangan Daerah, Dan Sistem 
Pengendalian Intern (Internal Audit) Terhadap Kualitas Laporan Keuangan Pemerintah Daerah (Studi Empiris pada SKPD Kabupaten Kuantan Singingi). JOM FEKON Vol. 1 No. Oktober 2014.

Zalni, Fitri. 2013. Pengaruh Komitmen Karyawan dan Penerapan Sistem Pengendalian Intern Pemerintah (SPIP) Terhadap Pengelolaan Keuangan Daerah (Studi Empiris Pada DPKD Pemerintah Kota Di Sumatera Barat). 